\title{
Genetic alterations of tumor suppressor ING1 in human non-small cell lung cancer
}

\author{
ZHI-GANG LUO $^{1 *}$, HAO TANG $^{2 *}$, BING LI $^{2}$, ZHI ZHU $^{1}$, CAN-RONG NI $^{1}$ and MING-HUA ZHU ${ }^{1}$ \\ ${ }^{1}$ Department of Pathology, Changhai Hospital, Second Military Medical University, Shanghai 200433; ${ }^{2}$ Department \\ of Respiratory Disease, Changzheng Hospital, Second Military Medical University, Shanghai 200003, P.R. China
}

Received November 19, 2010; Accepted December 29, 2010

DOI: 10.3892/or.2011.1172

\begin{abstract}
The aim of this study was to investigate the function of the ING1 gene in lung carcinoma. To detect the inhibitory effect of ING1 in human lung cancer, recombinant ING1b plasmids were transfected into two lung cancer cell lines with different p53 status, A549 with wild-type p53 (wtp53) and SK-MES-1 with mutant p53. Apoptosis, cell cycle, growth rate and the expression of downstream gene p21waf1 were analyzed. In addition, the complex of p33ING1b and p53 was analyzed with coimmunoprecipitation. To detect the gene alteration and the expression of ING1, 70 cases of fresh-frozen lung carcinomas and 217 cases of formalin-fixed, paraffin-embedded specimens were examined for loss of heterozygosity (LOH) and p33ING1b protein expression by polymerase chain reaction single-strand conformation polymorphism (PCR-SSCP) and immunohistochemistry using tissue microarrays, respectively. Overexpression of ING1b inhibited the cell growth of A549 and SK-MES-1, induced cell cycle arrest and apoptosis. p21waf1 was up-regulated and a complex of p33ING1b and wtp53 was found after transfection of ING1b in the wtp53-positive lung cancer cell. High LOH frequency was found in lung carcinomas (55.7\%) and $\mathrm{p} 33 \mathrm{ING1b}$ expression was lost in 115 of 217 carcinomas (53.0\%). Furthermore, there was a highly significant inverse correlation between expression and $\mathrm{LOH}$ frequency $(\mathrm{P}<0.05)$. ING1 can inhibit the growth of lung cancer cell lines through the induction of cell cycle arrest and apoptosis by forming a complex with wtp53 and up-regulating p21waf1. In human
\end{abstract}

Correspondence to: Dr Ming-Hua Zhu, Department of Pathology, Changhai Hospital, Second Military Medical University, 168 Changhai Road, Shanghai 200433, P.R. China

E-mail: zhuminghuali@yahoo.com.cn

Dr Bing Li, Department of Respiratory Disease, Changzheng Hospital, Second Military Medical University, 415 Fengyang Road, Shanghai 200003, P.R. China

E-mail: lbxwzhao@yahoo.com.cn

${ }^{*}$ Contributed equally

Key words: lung carcinoma, ING1, apoptosis, cell cycle arrest lung cancer, expression of the ING1 gene was reduced or lost and high LOH frequency of ING1 microsatellites was found. The LOH of microsatellites may down-regulate p33ING1b and/or affect its function, thereby, contributing to lung cell carcinogenesis.

\section{Introduction}

ING1, was identified as an inhibitor of growth and has been described as a tumor suppressor. ING1 has been suggested to play an important role in cell cycle control and apoptosis through cooperation with $\mathrm{p} 53$, which was verified by immunoprecipitation in vitro. ING1 gene is mapped on the human chromosome 13q33-34 and encodes several differentially initiated and spliced mRNAs, which have common 3' exon and encode at least two distinct proteins in mice, and possibly three distinct proteins in humans. The p33ING1b is the main product. In breast carcinoma, oral/esophageal squamous cell carcinoma, gastric carcinoma, malignant lymphoma and hepatocarcinoma, the expression of p33ING1b was lost or down-regulated and rare mutation was found in the three exons, but high loss of heterozygosity ( $\mathrm{LOH})$ of ING1 gene microsatellites was found in head and neck squamous cell carcinoma, exocrine pancreatic carcinoma and esophageal squamous cell carcinoma.

Lung cancer is the commonest cause of cancer death among men and women in the world. The most important and cost-effective management for lung cancer is smoking cessation, but for those with the disease, novel agents and treatment approaches are urgently needed. Gene therapy is an exciting prospect for treatment and potential cure of lung cancer and the outcome of a clinical trial of retrovirus-mediated p53 gene transfer to tumors of patients with lung cancer was effective in almost $60 \%$ of the patients. But some cancers were resistant to 553 gene therapy in vitro and in vivo, while $\mathrm{p} 33 \mathrm{INGlb}$ may enhance the stability of p53 and prolong its half-life and block cell proliferation, induce cell cycle arrest and apoptosis.

In this study, we investigated whether liposome-mediated gene transfer of the ING1 can inhibit the growth of human lung cancer cells, and whether ING1 interact with p53 in lung cancers. To investigate whether gene alteration affect the expression of ING1 in lung cancer tissues, we analyzed the LOH of ING1 gene microsatellites and the abnormal expression of p33ING1b in 207 cases of lung cancers. 
Table I. Primer sequences for microsatellites of ING1 gene.

\begin{tabular}{llcc}
\hline MS locus & \multicolumn{1}{c}{ Primer sequences (5'-3') } & Sizes of PCR products (bp) & Tm $\left({ }^{\circ} \mathrm{C}\right)$ \\
\hline D13S261 & 5'-CACCCTCAATCTCAACCCAC-3' & $166-172$ & 55 \\
& 5'-GGAATGTGCTCTAATGCTGC-3' & & 55 \\
D13S1047 & 5'-CACATGCATATGCGCATGGAC-3' & 154 & \\
& 5'-CACATGCATATGCGCATGGAC-3' & $162-180$ & 55 \\
D13S1315 & 5'-TACACGATAAGTAAGCCAAGCA-3' & & 60 \\
& 5'-AACTCAACAGTCACAAGAGCAAT-3' & 124 & \\
& 5'-TGCCGCTGTGGAAGCTGG-3' & & \\
\hline
\end{tabular}

\section{Materials and methods}

Cell lines and plasmids. The human lung cancer cell lines, A549 (wild-type p53) and SK-MES-1 (p53 mutant) were kept in our laboratory. The A549 cells were growing in DMEM containing $10 \%$ fetal bovine serum and SK-MES-1 cells were growing in DMEM containing $10 \%$ fetal bovine serum and 0.1 $\mathrm{mM}$ non-essential amino acids, all cells were maintained under an atmosphere of $5 \% \mathrm{CO}_{2}$ at $37^{\circ} \mathrm{C}$ for 5 days before the assay of transduction efficiency was performed. Recombinant pcDNA3ING1b plasmid and recombinant plasmids pCMV containing sense wild-type p53 gene were constructed in our laboratory.

Lung cancer tissue samples. Seventy cases of fresh-frozen lung cancer tissues and its surroundings, 270 cases of formalin-fixed, paraffin-embedded specimens were obtained from the Department of Pathology, Changhai Hospital, Second Military Medical University. The patients' clinical records, histopathological diagnoses [according to the WHO classification (1)] and clinical stage (2) were fully documented.

Transient transfection. To detect the inhibitory effect of p33ING1b and p53 gene upon the growth of lung cancer cells, $1 \times 10^{6}$ cells of A549 and SK-MES-1 were plated overnight and transfected with plasmids pcDNA3-ING1b and pCMV-wtp53 respectively or commonly by Lipofectamine 2000 (Invitrogen) following the manufacturer's instructions. The plasmids used in transfection were divided into four groups: i) pcDNA3; ii) pcDNA3-ING1b; iii) pCMV-wtp53; and iv) co-transfection of pcDNA3-ING1b and pCMV-wtp53. Cells were harvested $48 \mathrm{~h}$ after transfection.

Apoptosis and cell cycle arrest assay. Forty-eight hours after transfection, cell apoptosis was assayed by Facscalibur flow cytometry (Becton-Dickinson, USA) using Annexin V-FITC apoptosis detection kit (BD PharMingen, USA). Cells were collected, washed twice with cold PBS and resuspended in binding buffer $(10 \mathrm{mmol} / \mathrm{l}$ Hepes/ $\mathrm{NaOH} \mathrm{pH} 7.4,140 \mathrm{mmol} / \mathrm{l}$ $\mathrm{NaCl}, 2.5 \mathrm{mmol} / 1 \mathrm{CaCl}_{2}$, sterile filtered) at a concentration of $1 \times 10^{6}$ cells $/ \mathrm{ml}$. The solution $(100 \mathrm{ml})$ was transferred to a $5-\mathrm{ml}$ culture tube, and $5 \mu \mathrm{l}$ of Annexin V-FITC and $5 \mu \mathrm{l}$ of propidium iodide were added, then the cells were gently ortexed and incubated for $15 \mathrm{~min}$ at room temperature in the dark. Cell cycle was analyzed by the same flow cytometry using Cycle test plus DNA reagent kit (Becton-Dickinson, $\mathrm{CA}$ ) following instructions of the manufacturer. All these assays were repeated at least twice.

Growth curve of lung cancer cell lines. After transient transfection, the cells were selected in $1000 \mu \mathrm{g} / \mathrm{ml}$ of G418 (Gibco-BRL) for 3 weeks. All resistant colonies were tripsinized and grown in complete medium. Resistant colonies of A549 and SK-MES-1 cells were grown in complete medium and the number of viable cells was determined at daily intervals by MTT assay for 7 days after seeding.

Western blot analysis and immunohistochemistry assay. p33ING1b monoclonal antibody (3) (kindly provided by Dr Karl Riabowol), p53 and p21waf1 monoclonal antibodies (Santa Cruz, USA), were used to analyze the protein products $48 \mathrm{~h}$ after transient transfection by Western blot analysis. The same p33ING1b and p53 antibodies and PCNA antibody (MIB-1, Dako) were used to analyze the protein expression in formalin-fixed, paraffin-embedded specimens of lung cancers through tissue microarray.

Coimmunoprecipitation assays of complex of p33ING1b and p53 coimmunoprecipitation on purified fractions has been described previously (4). For coimmunoprecipitation in whole-cell extracts, proteins were isolated from 150-ml cell cultures grown in DMEM to an optical density (OD) of 2.5. Cells were washed in 0.1M PBS ( $\mathrm{pH} 7.4$ ) and resuspended in $1 \mathrm{ml}$ of lysis buffer [50 mM Tris- $\mathrm{HCl}$ (pH7.5), 1\% NP-40, $0.25 \%$ Na-deoxycholate, $150 \mathrm{mM} \mathrm{NaCl}, 1 \mathrm{mM}$ ethylenediamine tetraacetic acid, $1 \mathrm{mM}$ phenylmethylsulfonyl fluoride, $1 \mathrm{mM} \mathrm{NaVo}, 1 \mathrm{mM} \mathrm{NaF}, 1 \mu \mathrm{g}$ of leupeptin, aprotinin and pepstatin $/ \mathrm{ml}$ ). Cell lysates were centrifugated $(30 \mathrm{~min}$ at $14,000 \times \mathrm{g}$ ) at $4^{\circ} \mathrm{C}$. Ten milligrams of total proteins was used in 500- $\mu \mathrm{l}$ immunoprecipitation reactions. Then, $50 \mu \mathrm{l}$ of protein A/G-Sepharose beads was used to preclear the lysate. Cross-linked anti-p53 protein A/G-Sepharose beads were then added, and the mixture was incubated overnight at $4^{\circ} \mathrm{C}$. The beads were washed three times with 10 volumes of $100 \mathrm{mM}$ $\mathrm{NaCl}$ lysis buffer. Input and immunoprecipitated proteins were analyzed by Western blot analysis.

LOH analysis by polymerase chain reaction-single strand conformation polymorphism (PCR-SSCP). To examine allelic loss in ING1 location, we selected four microsatellite 

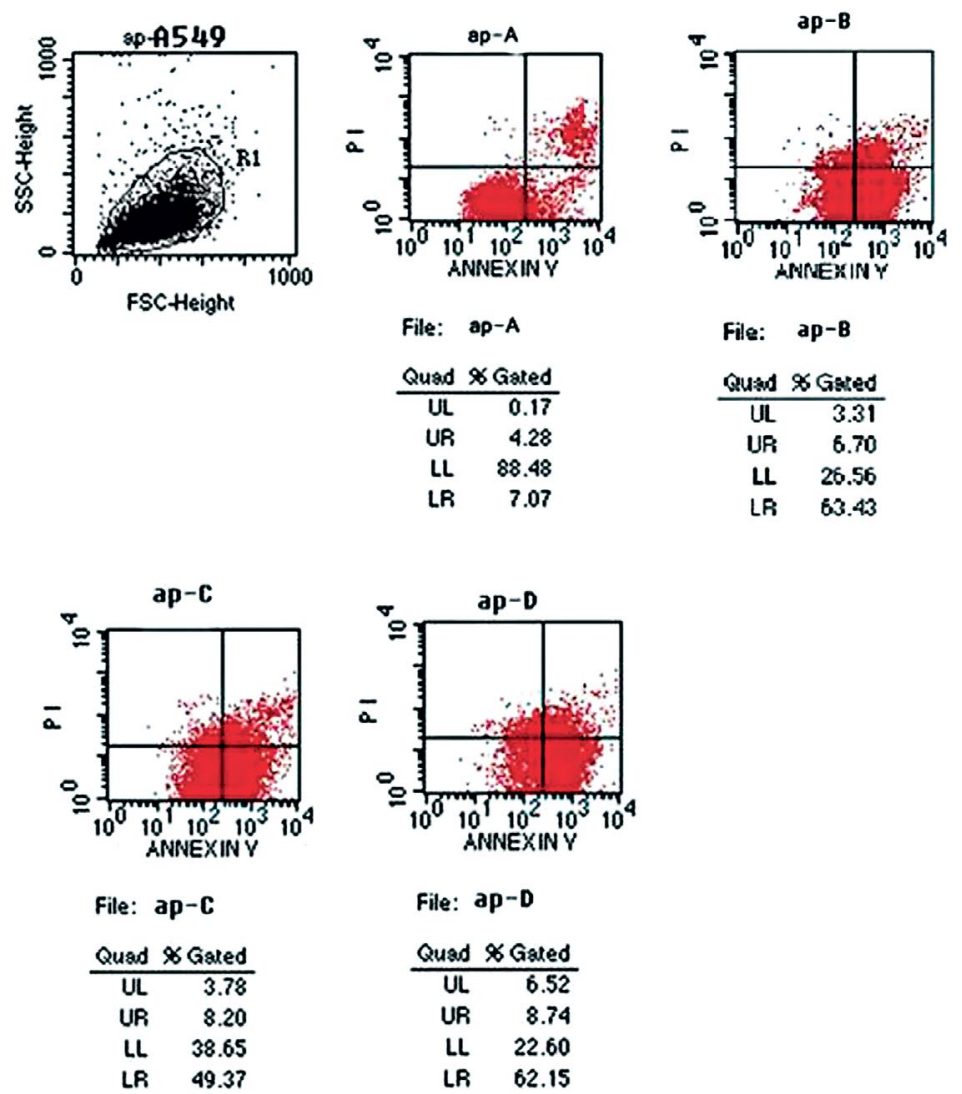

Figure 1. The apoptosis rates of A540 cells after trasfection with different plasmids: ap-A, pcDNA3; ap-B, pcDNA3/ING1b; ap-C, pCMV/wtp53; ap-D, pcDNA3/ING1b+pCMV/wtp53.

markers D13S261, D13S1047, D13S1315, and DS42490 on chromosome 13q33-34 which covered a relatively wide chromosomal area including ING1 gene. Genomic DNA was isolated from 70 cases of fresh-frozen lung cancer tissues and its matched surroundings by SDS/proteinase K treatment, phenol-chloroform extraction, and ethanol precipitation. Tumor tissues were not microdissected. However, it has been confirmed that by $\mathrm{H} \& \mathrm{E}$ staining during initial diagnosis, tumor cell ratio in samples is over 70\%. Primers for amplification of microsatellite markers D13S261, D13S1047, D13S1315 and DS42490 are available through the internet genome database (http://www.gdb.org) (Table I). PCR amplification was carried out in $20 \mu \mathrm{l}$ of reaction mixture as described (5). Initial denaturation at $94^{\circ} \mathrm{C}$ for $3 \mathrm{~min}$ was followed by 35 cycles of a denaturation step at $94^{\circ} \mathrm{C}$ for $30 \mathrm{sec}$, an annealing step for $1 \mathrm{~min}$, and an extension step at $72^{\circ} \mathrm{C}$ for $1 \mathrm{~min}$. A final extension step at $72^{\circ} \mathrm{C}$ for 7 min was added. After 35 cycles, $1 \mu \mathrm{l}$ of PCR product was mixed with $8 \mu \mathrm{l}$ of loading dye (95\% formamide, $20 \mathrm{mmol} / \mathrm{l}$ EDTA $0.05 \%$ bromophenol blue, and $0.05 \%$ xylene cyanol), heat denatured, chilled on ice, and applied onto $8 \%$ polyacrylamide gel with $5 \%$ glycerol. Silver staining was carried out as reported previously (5). LOH was scored if one of the heterozygous alleles showed at least $50 \%$ reduced intensity in tumor DNA as compared with the corresponding normal DNA (5).

Statistical analysis. The relationship between p33ING1b and p53 protein positive staining was evaluated using Wilcoxon signed rank test. The growth of different cells with different treatment was analyzed by Student's t-test. All data are presented as the mean \pm SD. A P-value $<0.05$ was considered statistically significant.

\section{Results}

INGIb induces apoptosis and cell cycle arrest drastically in lung cancer cell lines. After treatment, the apoptosis rate of A549 and SK-MES-1 cells were elevated especially in A549 cells with endogenous wild-type p53 gene, the elevation extent of A549-pcDNA3-ING1b $(62.31 \pm 1.37 \%)$ was significantly higher than SK-MES-1-pcDNA3-ING1b cells with mutant p53 $(26.74 \pm 1.32 \%),(\mathrm{P}<0.01$, Figs. 1 and 2$)$.

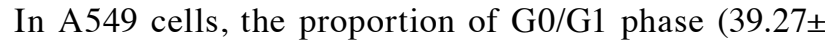
$1.33 \%)$ was much higher than cells transfected with vector $(30.71 \pm 0.56 \%)$ and co-transfected cells with pCMVwtp53 $(45.21 \pm 1.29)$ was higher than pcDNA3-p33ING1b $(39.27 \pm 1.33 \%)$ or pCMV-wtp53 $(42.62 \pm 1.02 \%)$ solo. The proportion of SK-MES-1-pcDNA3-p33ING1b cells arrested at G0/G1 phase $(39.15 \pm 0.65 \%)$ was much more than cells transfected with vector $(35.03 \pm 1.67 \%)$ and co-transfected cells with pCMV-wtp53 (45.03 $\pm 0.94 \%)$ was higher than pcDNA3p33ING1b or pCMV-wtp53 $(37.32 \pm 1.01 \%)$ solo $(\mathrm{P}<0.05$, Figs. 3 and 4).

Overexpression of p33ING1b inhibits lung cancer cellular growth and survival. The growth curve of A549 cells showed 

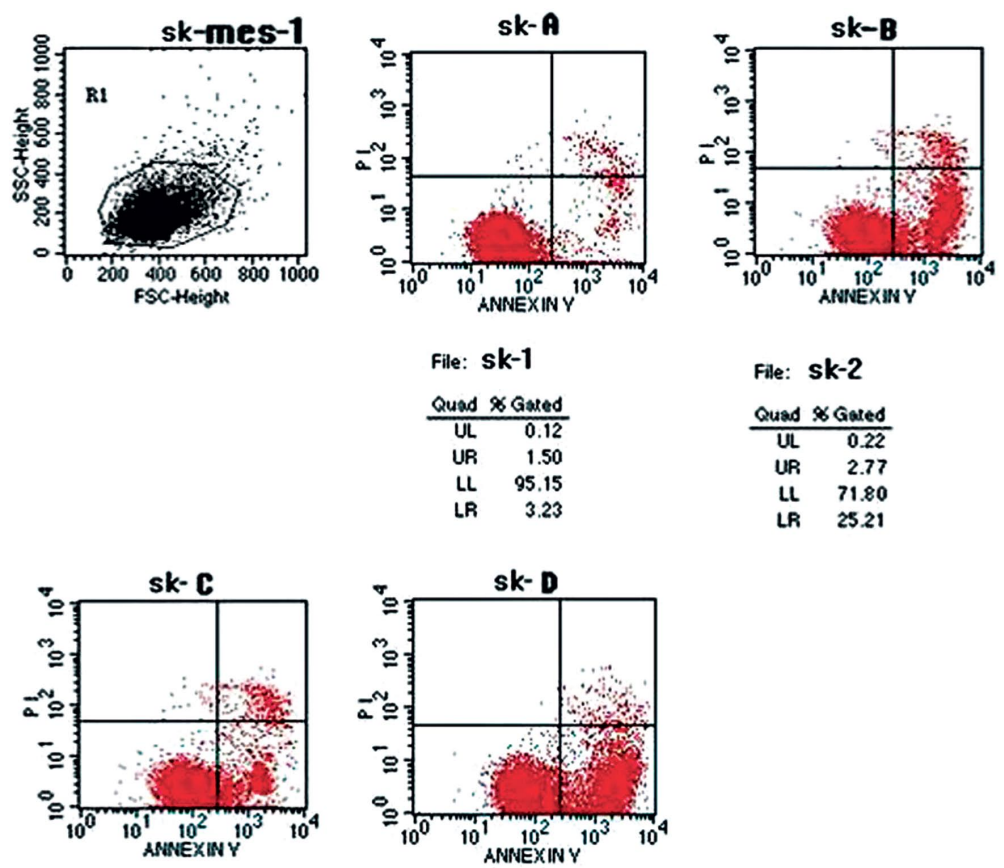

File: $\mathbf{s k - 3}$

File: $\mathbf{s k - 4}$
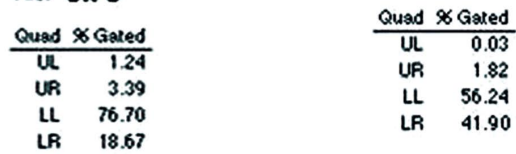

Figure 2. The apoptosis rates of SK-MES-1 cells after trasfection with different plasmids: sk-A, pcDNA3; sk-B, pcDNA3/ING1b; sk-C, pCMV/wtp53; sk-D, pcDNA3/ING1b+pCMV/wtp53.
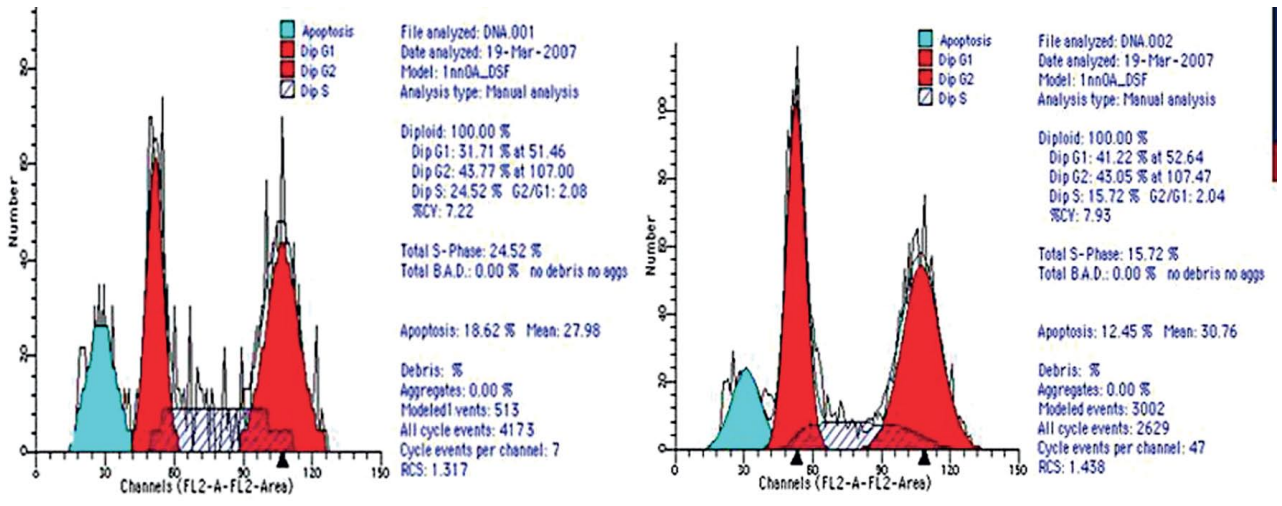

A

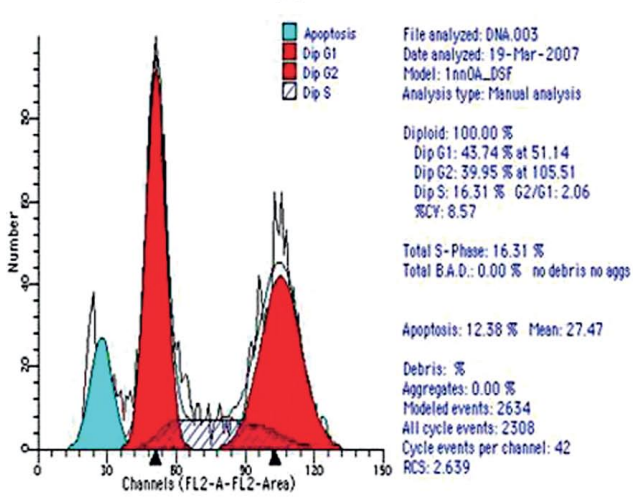

C

B

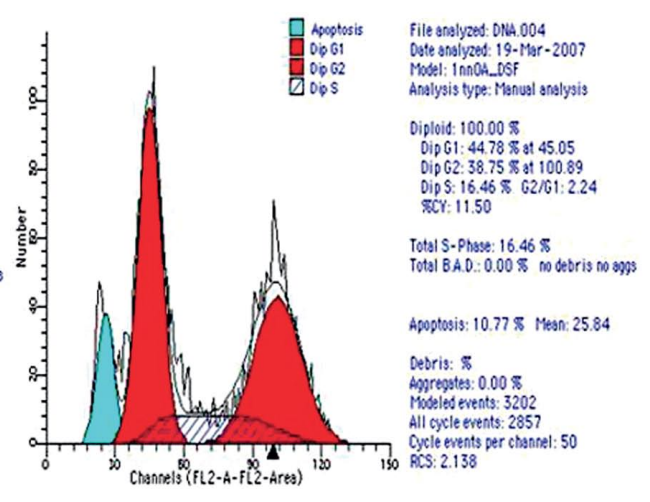

D

Figure 3. The cell cycle change of A540 cells after trasfection with different plasmids: (A) pcDNA3; (B) pcDNA3/ING1b; (C) pCMV/wtp53; (D) pcDNA3/ ING1b+pCMV/wtp53. 

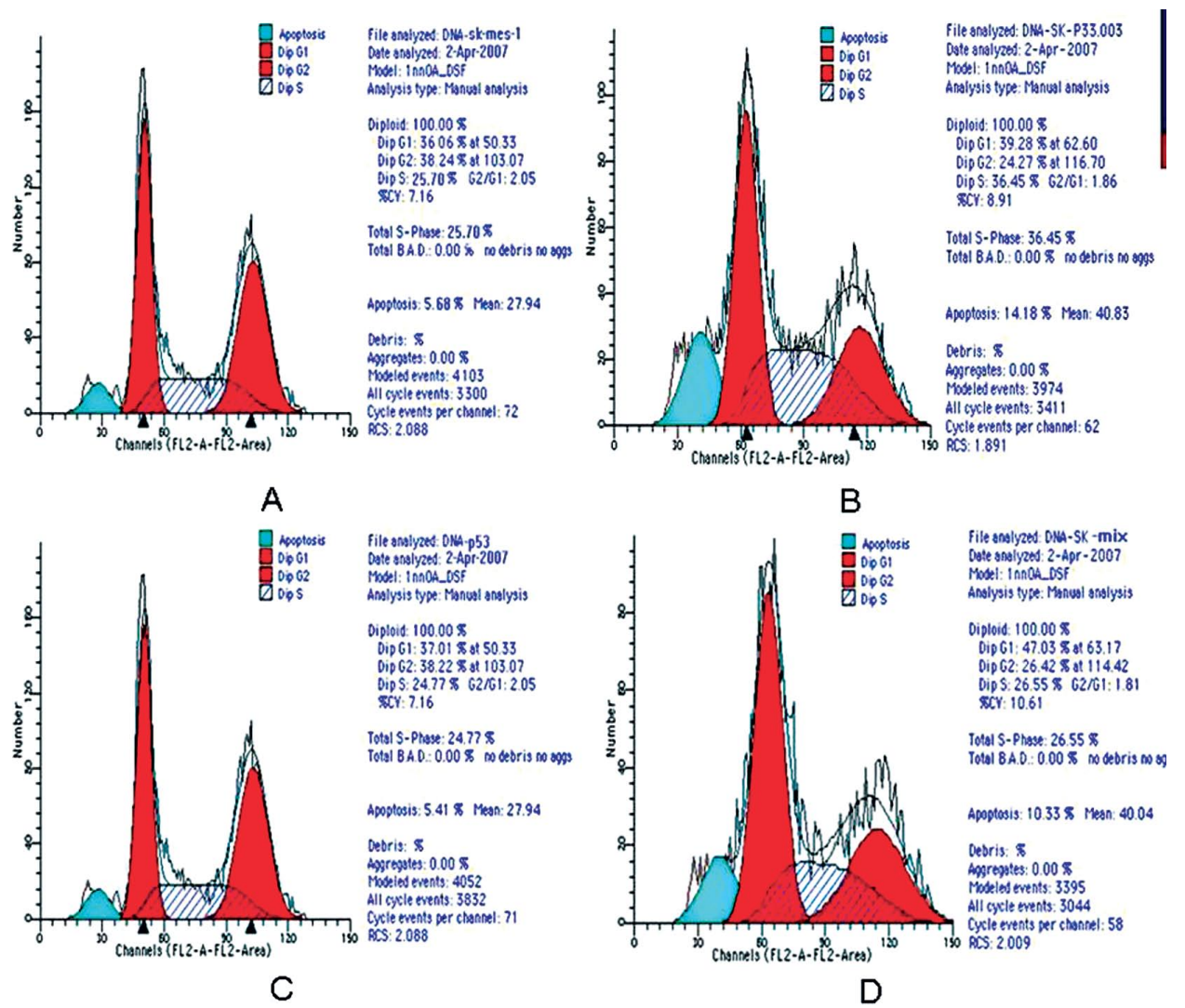

Figure 4. The cell cycle change of SK-MES-1 cells after trasfection with different plasmids: (A) pcDNA3; (B) pcDNA3/ING1b; (C) pCMV/wtp53; (D) pcDNA3/ING1b+pCMV/wtp53.

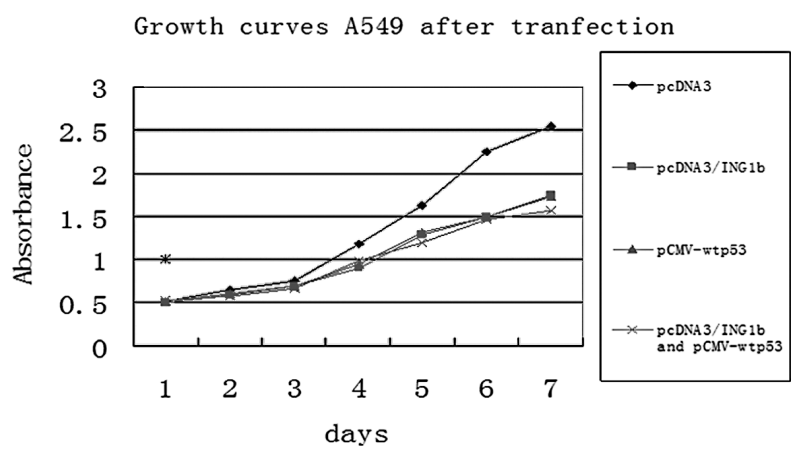

Figure 5. The growth curves of A549 cells after transfection.

stably transfected cells with pcDNA3-p33ING1b plasmid grew significantly slower than cells with pcDNA3 plasmid $(\mathrm{P}<0.01)$, and the cotransfected cells with pCMV-wtp53 grew much slower $(\mathrm{P}<0.01$, Fig. 5$)$. While the growth of SK-MES-1 cells was not as slow as A549 ( $\mathrm{P}<0.01$, Fig. 6).

p33ING1b combines with wild-type p53 and activates the p53 downstream gene p21waf1. Western-blot assay found that the expression of p21waf1 was up-regulated in the A549-pcDNA3-ING1b and SK-MES-1-pcDNA3-ING1b+ pCMV-wtp53 cells (Fig. 7). The results of coimmunoprecipitation assay showed that the complex of p33ING1b and p53 in the A549-pcDNA3-ING1b cells of cotransfected A549 cells with pcDNA3-ING1b and pCMV-wtp53 (Fig. 8), while the

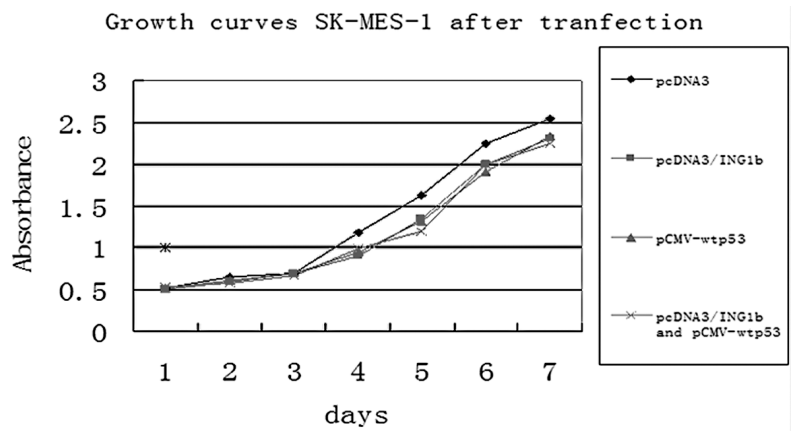

Figure 6. The growth curves of SK-MES-1 cells after transfection.

complex p33ING1b and p53 did not exist in the lung cancer tissues of p33ING1b and p53 immunoactivity.

Expression of p33ING1b and p53 in lung cancers. Immunohistochemistry results revealed that both p33ING1b and p53 proteins were nuclear positive in all paraffin embedded tissues from 217 cases of lung cancer (Table II). p33ING1b expression was found in 102 of 217 carcinomas (47.0\%) totally, and was found in $66.7 \%$ (62/93), 33.3\% (23/69), 37.9\% (11/29), $15.4 \%(2 / 13), 44.4 \%(4 / 9), 0 \%(0 / 3)$ and $0 \%(0 / 1)$ of squamous carcinoma (SCC), adenocarcinoma (AC), bronchioloalveolar carcinoma (BAC), adenosquamous carcinoma (AdCa), small cell lung carcinoma (SCLC), carcinoid and mucoepidermoid carcinoma, respectively (Fig. 9). The p33ING1b positivity in 


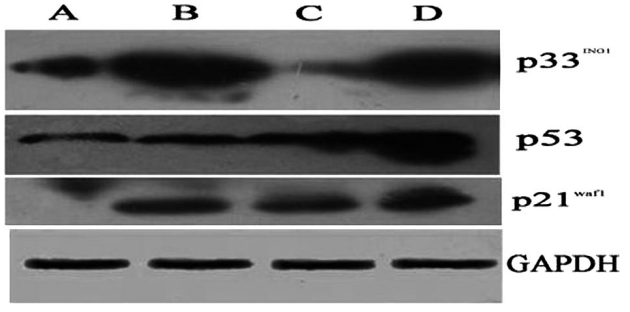

Figure 7. The expression of p33ING1b, p53 and p21waf1 after transfection with different plasmids: (A) pcDNA3; (B) pcDNA3/ING1b; (C) pCMV/ wtp53; (D) pcDNA3/ING1b+pCMV/wtp53.
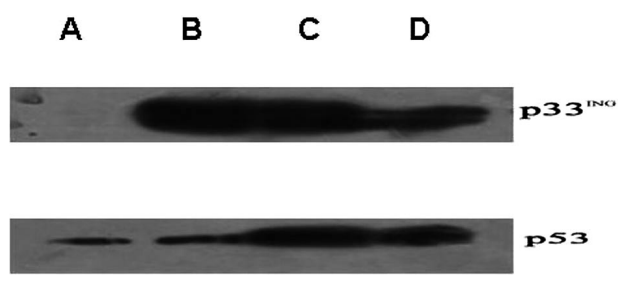

Figure 8 . Western blot assay with antibody p33ING1b after immunoprecipitating with p53(a) and the reverse (b). The four cell groups were transfected with (A) pcDNA3; (B) pcDNA3/ING1b; (C) pCMV/wtp53; (D) pcDNA3/ ING1b+pCMV/wtp53.

SCC was significantly higher $(\mathrm{P}<0.05)$ than $\mathrm{AC}, \mathrm{BAC}$, and $\mathrm{AdCa}$, while there was no significantly difference between other types. The expression of p33ING1b has a positive correlation with p53 (Wilcoxon test, $\mathrm{r}=0.53520, \mathrm{P}<0.01$ ) while the p33ING1b expression was not correlated with the clinicopathological characteristics $(\mathrm{r}<0.12, \mathrm{P}>0.05)$.

LOH analysis of ING1 gene in lung cancers. Seventy cases of fresh-frozen lung cancers were analyzed with polymerase chain reaction-single trand conformation polymorphism
(PCR-SSCP) (Fig. 10, Tables II and III). LOH was found in 39 of 70 lung carcinomas $(55.7 \%)$ on four ING1 loci and found in 14, 17, 15, 28 carcinomas on D13S261, D13S1047, D13S1315 and DS42490, respectively. LOH on DS42490 located in the intron of ING1 gene was significantly higher than the other loci $(\mathrm{P}<0.05)$, but the $\mathrm{LOH}$ frequency was not correlation with clinicopathological characteristics $(\mathrm{P}>0.05)$. The p33ING1b expression was not correlated with the clinicopathological characteristics but there was a highly significant inverse correlation with LOH frequency (Table IV, $\mathrm{P}<0.05$ ).

\section{Discussion}

In this study, we found that overexpression of p33ING1b can inhibit cell growth, induce apoptosis and cell cyle arrest (G0/G1) of lung caner cell lines, A549 and SK-MES-1, especially in the A549 cells which expresses wild-type p53. In the transient transfected cells, overexpression of p33ING1b can up-regulate the p21waf1, and coimmunoprecipitation found the complex of p33ING1b and p53 existed. The results support that $\mathrm{p} 33$ ING1b can up-regulate p21waf1 through combinding p53 and then induce apoptosis and cell cyle arrest. p53 plays a great role in preventing carcinogenesis and in more than half of the tumors p53 is mutated, on the other hand, its interacting proteins can affect its function, such as MDM2, WT1, C-Abl. The p33ING1b is considered as a new member of these interacting proteins $(6,7)$.

Previous studies also found the suppression of p33ING1 expression promoted focus formation and growth in vitro and tumor formation in vivo, whereas ectopic overexpression of this protein blocked cell cycle progression by arresting transfected cells at G1 of the cell cycle (8). p33ING1b is considered to disrupt the interaction between p53 and MDM2 leading to the stabilization of p53 and growth inhibition through binding to the $\mathrm{NH} 2$-terminal region of $\mathrm{p} 53$, the same region as MDM2. The C-terminal region of the p33ING1b molecule

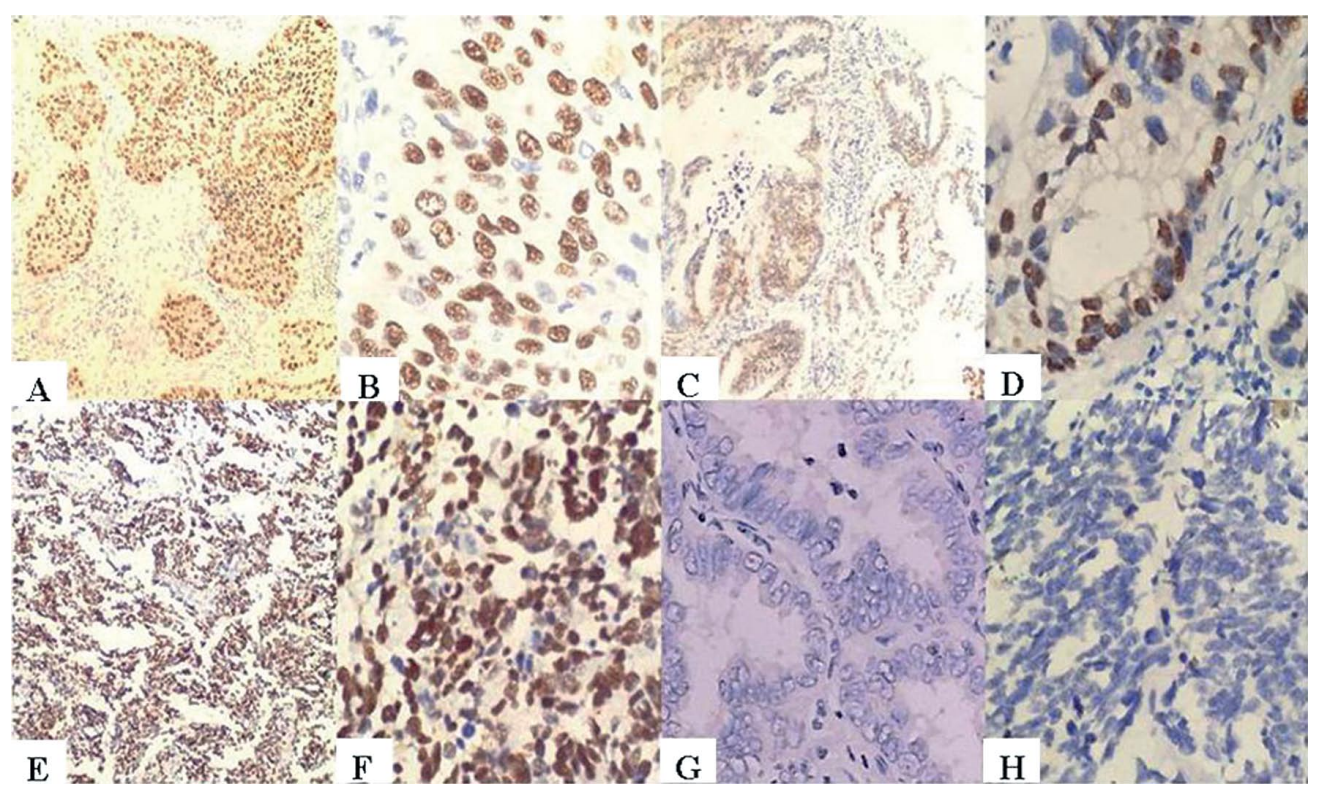

Figure 9. Immunohistochemistry staining of lung carcinomas. p33INGlb positive immunoactivity is yellow or buffy and located in the nuclei of carcinoma cells (A-F). (A) Low power microscope of SCC, (B) high power microscope of SCC, (C) low power microscope of AC, (D) high power microscope of AC, (E) low power microscope of SCLC, (F) high power microscope of SCLC, (G and H) negative immunoactivity of AC and SCLC, respectively. 
Table II. The relationship between the expression of p33ING1b, LOH of ING1 gene microsatellites and clinicopathological characteristics.

\begin{tabular}{|c|c|c|c|c|c|c|}
\hline $\begin{array}{l}\text { Clinicopathological } \\
\text { characteristics }\end{array}$ & $\mathrm{IHC}(\mathrm{n})$ & p33ING1b positive $(\mathrm{n})(\%)$ & P-value & PCR-SSCP (n) & $\mathrm{LOH}(\mathrm{n})(\%)$ & P-value \\
\hline \multicolumn{7}{|l|}{ Gender } \\
\hline Male & 151 & $81(53.6)$ & \multirow[t]{2}{*}{$\mathrm{P}>0.05$} & 46 & $25(54.3)$ & \multirow[t]{2}{*}{$\mathrm{P}>0.05$} \\
\hline Female & 66 & $21(31.8)$ & & 24 & $14(58.3)$ & \\
\hline \multicolumn{7}{|l|}{ Age (year) } \\
\hline$<40$ & 9 & $3(33.3)$ & \multirow[t]{3}{*}{$\mathrm{P}>0.05$} & 3 & $2(66.7)$ & \multirow[t]{3}{*}{$\mathrm{P}>0.05$} \\
\hline $41-60$ & 99 & $41(41.4)$ & & 31 & $16(51.6)$ & \\
\hline$>60$ & 109 & $58(53.2)$ & & 36 & $21(58.3)$ & \\
\hline \multicolumn{7}{|l|}{ Histological type } \\
\hline $\mathrm{SCC}$ & 93 & $62(66.7)$ & $*$ & 25 & $12(48.0)$ & \multirow[t]{7}{*}{$P>0.05$} \\
\hline $\mathrm{AC}$ & 69 & $23(33.3)$ & & 28 & $15(53.6)$ & \\
\hline BCA & 29 & $11(37.9)$ & & 8 & $5(62.5)$ & \\
\hline $\mathrm{AdCa}$ & 13 & $2(15.4)$ & & 2 & $1(50.0)$ & \\
\hline SCLC & 9 & $4(44.4)$ & & 4 & $4(100)$ & \\
\hline Carcinoid & 3 & $0(0)$ & & 2 & $1(50.0)$ & \\
\hline $\begin{array}{l}\text { Mucoepidermoid } \\
\text { carcinoma }\end{array}$ & 1 & $0(0)$ & & 1 & $1(100)$ & \\
\hline \multicolumn{7}{|l|}{ Differenciation } \\
\hline Well & 25 & $15(60.0)$ & \multirow[t]{3}{*}{$\mathrm{P}>0.05$} & 9 & $5(55.6)$ & \multirow[t]{3}{*}{$\mathrm{P}>0.05$} \\
\hline Moderated & 95 & $52(54.7)$ & & 34 & $16(47.1)$ & \\
\hline Poor & 42 & $18(42.9)$ & & 10 & $5(50.0)$ & \\
\hline \multicolumn{3}{|l|}{ Size of tumor $(\mathrm{d} / \mathrm{cm})$} & \multirow[t]{4}{*}{$\mathrm{P}>0.05$} & & & \multirow[t]{4}{*}{$\mathrm{P}>0.05$} \\
\hline$\leq 3$ & 72 & $31(43.1)$ & & 23 & $12(52.2)$ & \\
\hline $3-6$ & 95 & $49(51.6)$ & & 30 & $16(53.3)$ & \\
\hline$\geq 6$ & 50 & $22(44.0)$ & & 17 & $11(64.7)$ & \\
\hline \multicolumn{3}{|l|}{ Pathological stage } & \multirow[t]{3}{*}{$\mathrm{P}>0.05$} & & & \multirow[t]{3}{*}{$P>0.05$} \\
\hline $\mathrm{I} / \mathrm{II}$ & 131 & $63(48.1)$ & & 35 & $16(45.7)$ & \\
\hline III/IV & 86 & $39(45.3)$ & & 35 & $23(65.7)$ & \\
\hline \multicolumn{7}{|l|}{ LN metastasis } \\
\hline Yes & 100 & $48(48)$ & \multirow[t]{3}{*}{$P>0.05$} & 31 & $17(54.8)$ & \multirow[t]{3}{*}{$P>0.05$} \\
\hline No & 117 & $54(46.2)$ & & 39 & $22(56.4)$ & \\
\hline Total & 217 & $102(47.0)$ & & 70 & $39(55.7)$ & \\
\hline
\end{tabular}

"The p33ING1b positivity in squamous carcinoma (SCC) was significantly higher than adenocarcinoma (AC), bronchioloalveolar carcinoma $(\mathrm{BAC})$, and adenosquamous carcinoma (AdCa) $(\mathrm{P}<0.05)$, while there was no significantly difference between other types $(\mathrm{P}>0.05)$.

harbours the PHD motif, which is thought to act as a macromolecule recognition domain (9). This facilitates the function of the PHD finger as both a regulator of transcription through interaction with RNA and DNA, and a regulator of chromatin remodelling through the targeting of nuclear recognition in chromatin structures. In contrast, the $\mathrm{N}$-terminal region is more involved with protein interactions (10-13).

Recent studies provide evidence that human ING1 proteins are involved in chromatin remodeling functions through stable physical association with protein complexes that have HAT and HDAC activity (12). Through co-IP and IAP-MS, many proteins co-precipitate with different isoforms of the ING1 family in large multi-subunit complexes, such as PCNA (14), HDAC1 (15,16), GADD45 (17), CBP (15). Therefore, the reduced or loss of expression of ING1 must affect the tumor inhibitory effect and lead to carcinogenesis. Reduced levels of p33ING1 have been found in breast $(8,18)$, neuroblastoma (19), and glioma cancer cell lines (8) and, testis (20), esophagus (21), and lymphoid (22) tissues.

Several mechanisms of malfunction of the ING1 gene have been proposed. These include: gene malfunctions [mutations, rearrangements, loss of heterozygosity $(\mathrm{LOH})$, homozygous loss, and DNA CpG island hypermethylation (23)], reduced mRNA expression, reduced protein expression, and protein malformations. In our study, p33ING1b expression was found in 102 of 217 carcinomas $(47.0 \%)$ in total, and was found in $66.7 \%$ (62/93), 33.3\% (23/69), 37.9\% (11/29), 15.4\% (2/13), $44.4 \%(4 / 9), 0 \%(0 / 3)$ and $0 \%(0 / 1)$ of squamous carcinoma 
Table III. LOH analysis of ING1 gene in lung cancers.

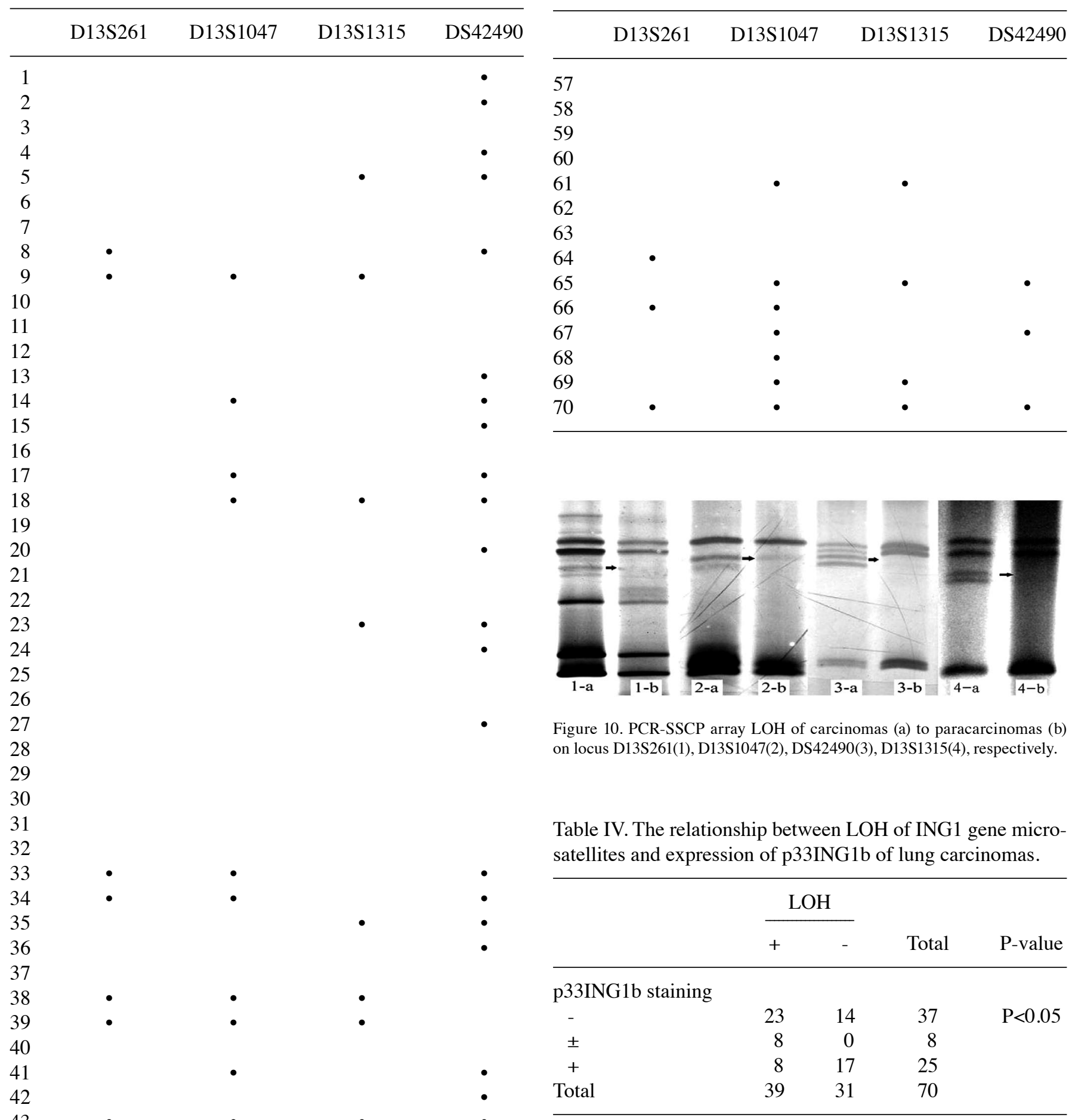

Table III. Continued.

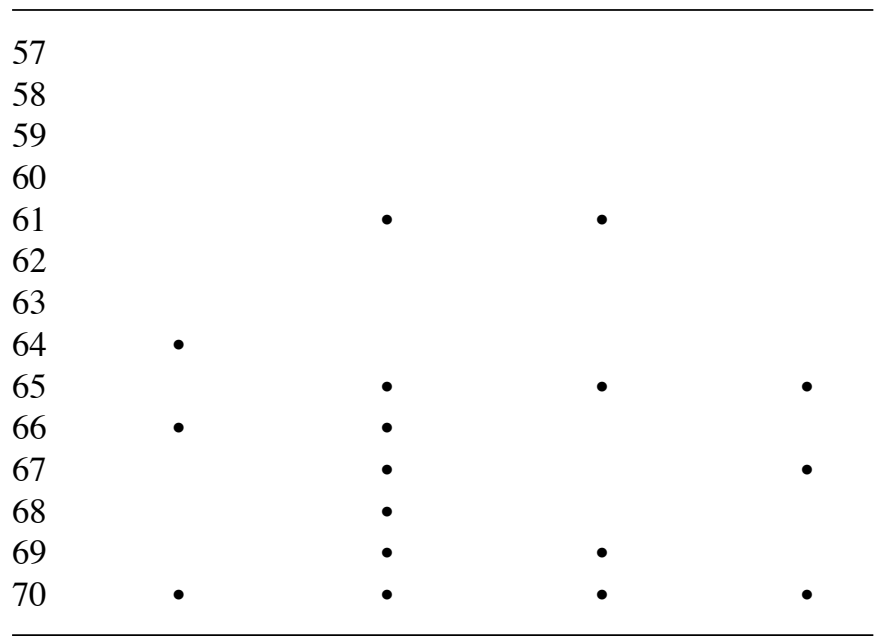

(SCC), adenocarcinoma (AC), bronchioloalveolar carcinoma (BAC), adenosquamous carcinoma (AdCa), small cell lung carcinoma (SCLC), carcinoid and mucoepidermoid carcinoma, respectively. The p33ING1b positivity in SCC was significantly higher $(\mathrm{P}<0.05)$ than $\mathrm{AC}, \mathrm{BAC}$, and $\mathrm{AdCa}$, while there was no significantly difference between other types. Further study found in 70 of the 217 lung cancers, high frequency of LOH of the loci of ING1 gene microsatellites and these were significantly correlated with the loss expression of p33ING1b. The LOH of microsatellites may change the DNA conformation and down-regulate the transcription then leading to reduced or loss of expression of the ING1 gene (24-26). The human ING1 
tumour suppressor gene has been mapped to the subtelomeric region of the long arm of chromosome 13 (13q33-34) (27). Both the RB (13q14) and the BRCA-2 (13q12) genes are located close to this locus $(28,29)$. High rates of $13 q \mathrm{LOH}$ have been detected in a variety of tumors, including those of the oesophagus, colorectum, kidney, urinary bladder, breast, ovary, lung, lymphoid cells, and head and neck (29-38).

In conclusion, p33ING1b cooperates with p53 in inhibiting lung cancer cells growth. And in lung cancer the loss of heterozygosity of microsatellites of ING1 gene may lead the loss or low expression of its main protein products and then cause lung carcinogenesis. Whether ING1 gene products interact with other proteins in lung cancer needs further investigation. The involvement of p33ING1b in p53 signaling pathway indicates that $\mathrm{p} 33 \mathrm{ING} 1 \mathrm{~b}$ is essential for $\mathrm{p} 53$ function, loss or inactivation of p33ING1b may contribute to malignant transformation of lung cancers retaining wild-type p53.

\section{Acknowledgements}

The authors thank Dr K. Riabowol for his generous gifts of p33ING1b monoclonal antibody.

\section{References}

1. Travis WD, Brambilla E and Muller-Hermelink HK: World health organization classification of tumours. Pathology and genetics of tumours of the lung, pleura, thymus and heart. Lyon LARC Press, pp26-67, 2004.

2. Hensing TA: Clinical evaluation and staging of patients who have lung cancer. Hematol Oncol Clin North Am 19: 219-235, 2005.

3. Garkavtsev I, Boland D, Mai J, et al: Specific monoclonal antibody raised against the p33ING1 tumor suppressor. Hybridoma 16: 537-540, 1997.

4. Garkavtsev I, Grigorian IA, Ossovskaya VS, et al: The candidate tumour suppressor p33ING1 cooperates with p53 in cell growth control. Nature 391: 295-298, 1998.

5. Gunduz M, Ouchida M, Fukushima K, et al: Genomic structure of the human ING1 gene and tumor-specific mutations detected in head and neck squamous cell carcinomas. Cancer Res 60 3143-3146, 2000

6.Garkavtsev I and Boucher Y: An intact ING1-P53 pathway can potentiate the cytotoxic effects of taxol. Cancer Biol Ther 4 48-49, 2005.

7. Zhu JJ, Li FB, Zhu XF, et al: The p33ING1b tumor suppressor cooperates with p53 to induce apoptosis in response to etoposide in human osteosarcoma cells. Life Sci 78: 1469-1477, 2006.

8. Garkavtsev I, Kazarov A, Gudkov A, et al: Suppression of the novel growth inhibitor p33ING1 promotes neoplastic transformation. Nat Genet 14: 415-420, 1996.

9. Gong W, Suzuki K, Russell M, et al: Function of the ING family of PHD proteins in cancer. Int J Biochem Cell Biol 37: 1054-1065, 2005.

10. Shimada Y, Saito A, Suzuki M, et al: Cloning of a novel gene (ING1L) homologous to ING1, a candidate tumor suppressor. Cytogenet Cell Genet 83: 232-235, 1998.

11. Scott M, Bonnefin P, Vieyra D, et al: UV-induced binding of ING1 to PCNA regulates the induction of apoptosis. J Cell Sci 114: 3455-3462, 2001

12. Feng X, Hara Y and Riabowol K: Different HATS of the ING1 gene family. Trends Cell Biol 12: 532-538, 2002.

13. Nouman GS, Anderson JJ, Lunec J, et al: The role of the tumour suppressor p33 ING1b in human neoplasia. J Clin Pathol 56: 491-496, 2003.

14. Zhou M, Gu L, Li F, et al: DNA damage induces a novel p53-survivin signaling pathway regulating cell cycle and apoptosis in acute lymphoblastic leukemia cells. J Pharmacol Exp Ther 303: 124-131, 2002.

15. Vieyra D, Loewith R, Scott M, et al: Human ING1 proteins differentially regulate histone acetylation. J Biol Chem 277: 29832-29839, 2002.
16. Kuzmichev A, Zhang Y, Erdjument-Bromage H, et al: Role of the Sin3-histone deacetylase complex in growth regulation by the candidate tumor suppressor p33(ING1). Mol Cell Biol 22: 835-848, 2002.

17. Cheung KJ Jr, Mitchell D, Lin P, et al: The tumor suppressor candidate p33(ING1) mediates repair of UV-damaged DNA. Cancer Res 61: 4974-4977, 2001

18. Toyama T, Iwase H, Watson P, et al: Suppression of ING1 expression in sporadic breast cancer. Oncogene 18: 5187-5193, 1999.

19. Takahashi M, Ozaki T, Todo S, et al: Decreased expression of the candidate tumor suppressor gene ING1 is associated with poor prognosis in advanced neuroblastomas. Oncol Rep 12: 811-816, 2004.

20. Jager D, Stockert E, Scanlan MJ, et al: Cancer-testis antigens and ING1 tumor suppressor gene product are breast cancer antigens: characterization of tissue-specific ING1 transcripts and a homologue gene. Cancer Res 59: 6197-6204, 1999.

21. Chen L, Matsubara N, Yoshino T, et al: Genetic alterations of candidate tumor suppressor ING1 in human esophageal squamous cell cancer. Cancer Res 61: 4345-4349, 2001.

22 Ohmori M, Nagai M, Tasaka T, et al: Decreased expression of p33ING1 mRNA in lymphoid malignancies. Am J Hematol 62: 118-119, 1999.

23. Auerkari EI: Methylation of tumor suppressor genes p16(INK4a), p27(Kip1) and E-cadherin in carcinogenesis. Oral Oncol 42: $5-13,2006$.

24. Sanchez-Cespedes M, Okami K, Cairns P, et al: Molecular analysis of the candidate tumor suppressor gene ING1 in human head and neck tumors with $13 \mathrm{q}$ deletions. Genes Chromosomes Cancer 27: 319-322, 2000.

25. Wei JB, Chen LS and Gao F: Mutation, loss of heterozygosity, and expression of tumor suppressor gene ING1 in sporadic colorectal carcinoma. Ai Zheng 24: 141-144, 2005.

26. Yu GZ, Zhu MH, Zhu Z, et al: Genetic alterations and reduced expression of tumor suppressor p33(ING1b) in human exocrine pancreatic carcinoma. World J Gastroenterol 10: 3597-3601, 2004.

27. Zeremski M, Horrigan SK, Grigorian IA, et al: Localization of the candidate tumor suppressor gene ING1 to human chromosome 13q34. Somat Cell Mol Genet 23: 233-236, 1997.

28. Takahashi M, Seki N, Ozaki T, et al: Identification of the p33(ING1)-regulated genes that include cyclin B1 and proto-oncogene DEK by using cDNA microarray in a mouse mammary epithelial cell line NMuMG. Cancer Res 62: 2203-2209, 2002.

29. Takahashi R: Role of the RB gene in carcinogenesis. Hum Cell 6: 260-265, 1993

30. Reissmann PT, Koga H, Takahashi R, et al: Inactivation of the retinoblastoma susceptibility gene in non-small-cell lung cancer. The Lung Cancer Study Group. Oncogene 8: 1913-1919, 1993.

31. Anglard P, Tory K, Brauch H, et al: Molecular analysis of genetic changes in the origin and development of renal cell carcinoma. Cancer Res 51: 1071-1077, 1991.

32. Cairns P, Proctor AJ and Knowles MA: Loss of heterozygosity at the RB locus is frequent and correlates with muscle invasion in bladder carcinoma. Oncogene 6: 2305-2309, 1991.

33. Shenson DL, Gallion HH, Powell DE, et al: Loss of heterozygosity and genomic instability in synchronous endometrioid tumors of the ovary and endometrium. Cancer 76: 650-657, 1995.

34. Motomura K, Nishisho I, Takai S, et al: Loss of alleles at loci on chromosome 13 in human primary gastric cancers. Genomics 2: 180-184, 1998.

35. Borg A, Zhang QX, Olsson $\mathrm{H}$, et al: Chromosome 1 alterations in breast cancer: allelic loss on $1 \mathrm{p}$ and $1 \mathrm{q}$ is related to lymphogenic metastases and poor prognosis. Genes Chromosomes Cancer 5: 311-320, 1992.

36. Mitelman F and Heim S: Chromosome abnormalities in cancer. Cancer Detect Prev 14: 527-537, 1990.

37. Maestro R and Dolcetti R: Oncogenes and tumor suppressor genes in head and neck squamous cell carcinomas. Acta Otorhinolaryngol Ital 16: 21-26, 1996.

38. Huang TH, Quesenberry JT, Martin MB, et al: Loss of heterozygosity detected in formalin-fixed, paraffin-embedded tissue of colorectal carcinoma using a microsatellite located within the deleted in colorectal carcinoma gene. Diagn Mol Pathol 2: 90-93, 1993. 